\title{
Menelisik Kesehatan Bank Menggunakan Metode Risk Based Bank Rating
}

\author{
Yasmir \\ Sekolah Tinggi Ilmu Administrasi Setih Setio \\ yasmir.ok1981@gmail.com
}

\begin{abstract}
The purpose of this study is to determine the health level of the Bank Pembangunan Daerah Jambi in 2015-2019. The object of research is the Regional Development Bank, one of which is an active role in increasing the development of each area where the shares are owned by the provincial government, based on Article 2 Number 13/1 / PBI. / 2011 point 2, Banks are required to conduct a soundness rating using a risk-based bank rating, both individually and on a consolidated basis. The results of the analysis of banking financial ratios using Risk Based Bank Rating indicate the condition of the financial performance of PT. Bank Pembangunan Daerah Jambi 2015-2019 from the aspect of Risk Profile NPL ratio meets bank standards except the Loan to Deposit Ratio does not meet the standards set by Bank Indonesia. In GCG analysis, which is an assessment of the quality of bank management on the implementation of GCG principles that has met bank standards. in the profitability ratio analysis, financial performance conditions can be said to be very good. In the analysis, the capital adequacy ratio has met Bank Indonesia's standards.
\end{abstract}

Keywords: RBBR; Risk Profile; GCG; Earning; Capital

\begin{abstract}
ABSTRAK
Tujuan dari penelitian ini adalah mengetahui tingkat kesehatan Bank Pembangunan Daerah Jambi pada tahun 2015-2019 objek penelitian Bank Pembangunan Daerah yang salah satunya perperan aktif dalam meningkatkan pembangunan daerah masing-masing dimana sahamnya dimiliki oleh pemerintah provinsi, berdasarkan Pasal 2 Nomor 13/1/PBI/2011 poin 2, Bank wajib melakukan penilaian tingkat kesehatan dengan menggunakan pendekatan risiko (Riskbased Bank Rating) baik secara individual maupun secara konsolidasi. Hasil analisis rasio keuangan perbankan menggunakan Risk Based Bank Rating menunjukkan kondisi kinerja keuangan PT. Bank Pembangunan Daerah Jambi tahun 2015-2019 dari aspek Risk Profil rasio NPL memenuhi standar bank kecuali Loan to Deposit Ratio tidak memenuhi standar yang ditetapkan Bank Indonesia. Pada analisis GCG yang merupakan penilaian terhadap kualitas manajemen bank atas pelaksanaan prinsip-prinsip GCG telah memenuhi standar bank. pada analisis rasio rentabilitas, kondisi kinerja keuangan dapat dikatakan sangat baik. Pada hasil analisis capital adequacy ratio telah memenuhi standar Bank Indonesia.
\end{abstract}

Kata Kunci : RBBR; Risk Profile; GCG; Earning; Capital 


\section{PENDAHULUAN}

Bank Pembangungan Daerah sebagai salah satu bank umum berperan sebagai pemegang kas daerah ditujukan sebagai mitra kerja pemerintah provinsi untuk mendukung program kerja pemerintah provinsi karena kepemilikan sahamnya dimiliki oleh pemerintah provinsi di berbagai daerah. Selain itu merupakan salah satu sumber pendapatan asli daerah dimana peran dan kontribusinya diharapkan untuk mendukung pertumbuhan ekonomi daerah dalam rangka meningkatkan tarap hidup masyarakat khususnya dan Indonesia umumnya.

Masyarakat sangat mengharapkan bank memberikan jaminan keamanan dana yang tersimpan melalui kinerja yang baik dan sehat dalam menjalankan kegiatan operasional secara normal dan memenuhi kewajibannya sesuai dengan peraturan perbankan yang berlaku.

Kesehatan bank menjadi kepentingan semua pihak, sehat dan tidaknya suatu bank menjadi penilaian kualitatif atas berbagai aspek yang berpengaruh terhadap kondisi atau kinerja suatu bank melalui penilaian kuantitatif dan atau penilaian kualitatif terhadap faktor permodalan, kualitas aset, manajemen dan rentabilitas.

Kesehatan bank merupakan kemampuan bank untuk melakukan kegiatan operasional perbankan secara normal dan mampu memenuhi kewajiban dengan baik dan dengan cara-cara yang sesuai peraturan perbankan yang berlaku (Budisusanto dan Trandaru, 20016). Hasil akhir penilaian kesehatan bank dapat digunakan sebagai salah satu sarana dalam menetapkan strategi usaha waktu yang akan datang sedangkan bagi Bank Indonesia antara lain dapat digunakan sebagai saran penetapan dan implementrasi strategi pengawasan bank oleh Bank Indonesia.

Peraturan Bank Indonesia No.13/ 1/ PBI/ 2011 yang dalam penilaiannya menggunakan pendekatan RGEC (Risk Profile, Good Corporate Governance, Earnings, Capital). Peraturan ini sekaligus menggantikan Peraturan Bank Indonesia sebelumnya yaitu Peraturan Bank Indonesia No. 6/ 10/ PBI/ 2004 Berdasarkan petunjuk teknis pelaksanaannya mengacu pada Surat Edaran Bank Indonesia Nomor 13/ 24/ DPNP pada tanggal 25 Oktober 2011, bahwa bank diwajibkan untuk melakukan penilaian sendiri (self assessment) tingkat kesehatan bank dengan menggunakan pendekatan risiko (Risk-based Bank Rating/ RBBR) baik secara individual maupun secara konsolidasi, dengan cakupan penilaian meliputi faktor profil risiko (Risk Profile), Good Corporate Governance (GCG), rentabilitas (Earnings), dan permodalan (Capital) untuk menghasilkan peringkat komposit tingkat kesehatan bank.

Berdasarkan Hasil penelitian (Ali Sadikin, Fahmi Roy, Dian Masita Dewi, Dahniar 2017) dilihat dari faktor Risk Profile Pada periode 2016 Bank Mandiri masuk kategori sangat sehat, Bank BRI masuk kategori sehat, Bank BTN masuk kategori cukup sehat, sedangkan Bank BNI masuk kategori kurang sehat. Dari faktor Good Corporate Governance pada Pada periode 2016 
Bank Mandiri, Bank BNI dan Bank BRI, masuk kategori sangat baik, sedangkan Bank BTN masuk kategori baik. Penilaian Faktor Earning pada Pada periode 2016 Bank Mandiri, Bank BNI, Bank BTN dan Bank BRI, masuk kategori sangat sehat. Penilaian dari faktor Capital Pada periode 2016 Bank Mandiri, Bank BNI, Bank BTN dan Bank BRI, masuk kategori sangat sehat sedang Penilaian tingkat kesehatan bank dilihat dari seluruh Faktor Pada periode 2016 Bank Mandiri, Bank BNI, Bank BTN dan Bank BRI, mendapat peringkat komposit sangat sehat.

Tujuan penelitian ini adalah menilai tingkat kesehatan bank dari faktor risk profile, good corporate governance, earning dan capital pada Bank Pembangunan Daerah Jambi secara keseluruhan selama periode 2015-2019. Alasan pemilihan objek penelitian ini Kesehatan Bank harus dipelihara dan/atau ditingkatkan agar kepercayaan masyarakat terhadap Bank dapat tetap terjaga. Selain itu, Tingkat Kesehatan Bank digunakan sebagai salah satu sarana dalam melakukan evaluasi terhadap kondisi dan permasalahan yang dihadapi Bank serta menentukan tindak lanjut untuk mengatasi kelemahan atau permasalahan Bank.

\section{Kesehatan Bank}

Menurut Peraturan Bank Indonesia Nomor 13/1/PBI/2011 kesehatan Bank harus dipelihara atau ditingkatkan agar kepercayaan masyarakat terhada Bank dapat tetap terjaga. Selain itu, tingkat kesehatan bank digunaka sebagai salah satu sarana dalam melakukan evaluasi terhadap kondisi dan permasalahan yang dihadapi Bank serta menentukan tindak lanjut untuk mengatasi kelemahan atau permasalahan Bank.

Kesehatan bank merupakan kepentingan semua pihak terkait, baik pemilik, manajemen bank, masyarakat pengguna jasa bank, Bank Indonesia dan Otoritas Jasa Keuangan selaku otoritas pengawasan perbankan dan pemerintah. (Amelia and Aprilianti 2019)

\section{Kesehatan Bank dengan pendekatan Risk Based Bank Rating (RBBR)}

Penilaian Tingkat Kesehatan Bank dengan menggunakan pendekatan risiko (Riskbased Bank Rating) dilakukan berdasarkan analisis yang komprehensif terhadap kinerja, profil risiko, permasalahan yang dihadapi, dan prospek perkembangan Bank. Menurut (Yacheva, Saifi, and A 2016) Metode penilaian tingkat kesehatan bank terdiri dari empat faktor penialaian, antara lain: Risk Profile (Profil Risiko), Good Corporate Governance (GCG), Earning (Rentabilitas), Capital (Permodalan). Namun, penilaian faktor Good Corporate Governance (GCG) tidak dapat dianalisa karena membutuhkan data primer yang menyangkut kerahasiaan bank. 


\section{Risk Profile (profil risiko)}

Penilaian faktor Profil Risiko merupakan penilaian terhadap Risiko inheren dan kualitas penerapan Manajemen Risiko dalam aktivitas operasional Bank. Risiko yang wajib dinilai terdiri atas 8 (delapan) jenis Risiko yaitu Risiko Kredit, Risiko Pasar, Risiko Operasional, Risiko Likuiditas, Risiko Hukum, Risiko Stratejik, Risiko Kepatuhan, dan Risiko Reputasi.

Dalam menilai Profil Risiko, Bank wajib pula memperhatikan cakupan penerapan Manajemen Risiko sebagaimana diatur dalam ketentuan Bank Indonesia mengenai Penerapan Manajemen Risiko bagi Bank Umum.

\section{NPL (Non Performing Loan)}

Merupakan rasio yang digunakan untuk menghitung persentase jumlah kredit yang bermasalah yang dihadapi oleh bank. Menurut surat edaran Bank Indonesia No. 13/24/DPNP tanggal 25 oktober 2011 pengukuran NPL menggunakan rumus :

$$
\text { NPL }=\frac{\text { Kredit bermaslah }}{\text { Total kredit }} \times 100 \%
$$

\section{LDR (Loan to Deposit Ratio)}

Loan to Deposit Ratio (LDR) merupakan perbandingan antara total kredit yang diberikan dengan total dana pihak ketiga. Semakin rendah LDR bank maka semakin likuid bank tersebut. Loan to Assets Ratio dirumuskan sebagai berikut (Kasmir, 2010: 286)

$$
\text { LDR }=\frac{\text { Kredit }}{\text { Dana pihak ketiga }} \times 100 \%
$$

\section{Good Corporate Governance (GCG)}

Penilaian faktor GCG merupakan penilaian terhadap kualitas manajemen Bank atas pelaksanaan prinsip-prinsip GCG. Prinsip-prinsip GCG dan fokus penilaian terhadap pelaksanaan prinsip-prinsip GCG berpedoman pada ketentuan Bank Indonesia mengenai Pelaksanaan GCG bagi Bank Umum dengan memperhatikan karakteristik dan kompleksitas usaha Bank.

Peringkat faktor GCG dikategorikan dalam 5 (lima) peringkat yaitu Peringkat 1 (sangat baik), Peringkat 2 (baik), Peringkat 3 (cukup baik), Peringkat 4 (kurang baik), dan Peringkat 5 (tidak baik). Urutan peringkat faktor GCG yang lebih kecil mencerminkan penerapan GCG yang lebih baik. 


\section{Earning (Rentabilitas)}

Penilaian faktor Rentabilitas meliputi evaluasi terhadap kinerja Rentabilitas, sumbersumber Rentabilitas, kesinambungan (sustainability) Rentabilitas, dan manajemen Rentabilitas. Penilaian dilakukan dengan mempertimbangkan tingkat, trend, struktur, stabilitas Rentabilitas Bank, dan perbandingan kinerja Bank dengan kinerja peer group, baik melalui analisis aspek kuantitatif maupun kualitatif.

Penilaian rentabilitas untuk menilai kemampuan bank dalam menghasilkan laba. Penilaian kuantitatif faktor rentabilitas dilakukan dengan melakukan penilaian terhadap Return On assets dan Net Interest Margin.

\section{a. Return On Assets (ROA)}

Return On Asset (ROA), merupakan rasio yang digunakan untuk mengukur kemampuan manajemen untuk menghasilkan income dari pengelolaan aset. Rumus yang digunakan sebagai berikut :

$$
\text { ROA }=\frac{\text { Laba sebelum pajak }}{\text { Rata }- \text { rata total aset }} \times 100 \%
$$

\section{b. Net Interest Margin (NIM)}

Net Interest Margin (NIM) merupakan rasio yang digunakan untuk mengukur kemampuan bank dalam menghasilkan pendapatan bunga bersih atas pengolahan besar aktiva produktif (PBI No.13/ 1/PBI/2011). Rasio ini menggambarkan tingkat jumlah pendapatan bunga bersih yang diperoleh dengan menggunakan aktiva produktif yang dimiliki oleh bank, jadi semakin besar nilai NIM maka akan semakin besar pula keuntungan yang diperoleh dari pendapatan bunga dan akan berpengaruh pada tingkat kesehatan bank. Perhitungan NIM adalah sebagai berikut:

$$
\mathrm{NIM}=\frac{\text { Pendapatan bunga bersih }}{\text { Total aktiva produktif }} \times 100 \%
$$

\section{Permodalan (Capital)}

Penilaian atas faktor Permodalan meliputi evaluasi terhadap kecukupan Permodalan dan kecukupan pengelolaan Permodalan. Dalam melakukan perhitungan Permodalan, Bank wajib mengacu pada ketentuan Bank Indonesia yang mengatur mengenai Kewajiban Penyediaan Modal Minimum bagi Bank Umum. Selain itu, dalam melakukan penilaian kecukupan Permodalan, Bank juga harus mengaitkan kecukupan modal dengan Profil Risiko Bank. Semakin tinggi Risiko Bank, semakin besar modal yang harus disediakan untuk mengantisipasi Risiko tersebut. 
Capital Adequacy Ratio (CAR) adalah rasio yang memperlihatkan seberapa jauh seluruh aktiva bank yang mengandung risiko (kredit, penyertaan, surat berharga, tagihan pada bank lain) ikut dibiayai dari dana modal sendiri bank. Nilai CAR yang semakin besar maka semakin aman dana deposan pada bank yang bersangkutan.(Farah 2012; Patni dan Darma, 2017). Capital Adequacy Ratio dirumuskan sebagai berikut (Kasmir, 2010: 286):

$$
\mathrm{CAR}=\frac{\text { Modal }}{\text { Aktiva Tertimbang Menurut Risiko }} \times 100 \%
$$

\section{METODE PENELITIAN}

Penelitian ini menggunakan data sekunder berupa laporan keuangan perusahaan dan laporan kinerja keuangan Bank Pembangunan Daerah Jambi Tahun 2015-2019, Jenis penelitian yang digunakan dalam penelitian ini adalah penelitian deskriptif dengan pendekatan kuantitatif, Metode analisis data dalam penelitian ini adalah (time series) runtun waktu menurut Wijaya, 2017 runtun waktu adalah membandingkan rasio pada waktu berbeda. Data yang digunakan adalah data yang diperoleh dari Bank pembangunan daerah Jambi periode tahun 2015-2019.

Data yang diperoleh pada penelitian ini dianalisa secara :

1. Menentukan matriks peringkat komposit tingkat kesehatan Bank

2. Perkembangan Bank Pembangunan Daerah Jambi periode 2015-2019 berdasarkan :

a. Risk Profile (Profil risiko) melalui dua rasio yaitu risiko kredit dengan rasio NPL dan risiko likuiditas dengan rasio LDR.

b. Earning (Rentabilitas) melalui dua rasio yaitu rasio ROA dan rasio NIM.

c. Good Corporate Governance (GCG)

d. Capital (Permodalan) dengan menggunakan rasio Capital Adequency Ratio (CAR).

3. Menganalisis tingkat kesehatan Bank Pembangunan daerah Jambi dengan cara membandingkan hasil perhitungan masing-masing rasio dari metode Risk Based Bank Rating dengan tingkat kesehatan bank. 


\section{HASIL DAN PEMBAHASAN}

\section{Tingkat Kesehatan Bank}

Berdasarkan Peraturan Bank Indonesia No.13/1/PBI/2011 dan SE No.13/24/DPNP tanggal 25 Oktober 2011 pada tabel dibawah ini :

\section{Tabel 1 \\ Peringkat Komposit Tingkat Kesehatan Bank}

\begin{tabular}{|c|c|}
\hline Peringkat & Penjelasan \\
\hline PK1 & $\begin{array}{l}\text { Mencerminkan kondisi Bank yang secara umum Sangat Sehat sehingga } \\
\text { dinilai sangat mampu menghadapi pengaruh negatif yang signifikan dari } \\
\text { perubahan kondisi bisnis dan faktor eksternal lainnya tercermin dari } \\
\text { peringkat faktor-faktor penilaian, antara lain profil risiko, penerapan GCG, } \\
\text { rentabilitas, dan permodalan yang secara umum sangat baik. Apabila } \\
\text { terdapat kelemahan maka secara umum kelemahan tersebut tidak } \\
\text { signifikan. }\end{array}$ \\
\hline PK2 & $\begin{array}{l}\text { Mencerminkan kondisi Bank yang secara umum Sehat sehingga dinilai } \\
\text { mampu menghadapi pengaruh negatif yang signifikan dari perubahan } \\
\text { kondisi bisnis dan faktor eksternal lainnya tercermin dari peringkat faktor- } \\
\text { faktor penilaian, antara lain profil risiko, penerapan GCG, rentabilitas, dan } \\
\text { permodalan yang secara umum sangat baik. Apabila terdapat kelemahan } \\
\text { maka secara umum kelemahan tersebut kurang signifikan. }\end{array}$ \\
\hline PK3 & $\begin{array}{l}\text { Mencerminkan kondisi Bank yang secara umum Cukup Sehat sehingga } \\
\text { dinilai Cukup mampu menghadapi pengaruh negatif yang signifikan dari } \\
\text { perubahan kondisi bisnis dan faktor eksternal lainnya tercermin dari } \\
\text { peringkat faktor-faktor penilaian, antara lain profil risiko, penerapan GCG, } \\
\text { rentabilitas, dan permodalan yang secara umum sangat baik. Apabila } \\
\text { terdapat kelemahan maka secara umum kelemahan tersebut Cukup } \\
\text { signifikan. Dan apabila tidak berhasil diatas dengan baik oleh manajemen } \\
\text { dapat mengganggu kelangsungan usaha Bank }\end{array}$ \\
\hline PK4 & $\begin{array}{l}\text { Mencerminkan kondisi Bank yang secara umum Kurang Sehat sehingga } \\
\text { dinilai Kurang mampu menghadapi pengaruh negatif yang signifikan dari } \\
\text { perubahan kondisi bisnis dan faktor eksternal lainnya tercermin dari } \\
\text { peringkat faktor-faktor penilaian, antara lain profil risiko, penerapan GCG, } \\
\text { rentabilitas, dan permodalan yang secara umum kurang baik. Apabila }\end{array}$ \\
\hline
\end{tabular}


terdapat kelemahan maka secara umum kelemahan tersebut Signifikan.

Dan tidak dapat diatasi dengan baik oleh manajemen serta mengganggu kelangsungan usaha Bank.

Mencerminkan kondisi Bank yang secara umum Tidak Sehat sehingga dinilai Tidak mampu menghadapi pengaruh negatif yang signifikan dari perubahan kondisi bisnis dan faktor eksternal lainnya tercermin dari peringkat faktor-faktor penilaian, antara lain profil risiko, penerapan GCG,

PK5 rentabilitas, dan permodalan yang secara umum kurang baik. terdapat kelemahan maka secara umum kelemahan tersebut Sangat Signifikan sehingga untuk mengatasinya dibutuhkan dukungan dana dari pemegang saham atau sumber dana dari pihak lain untuk memperkuat kondisi keuangan Bank.

Sumber: Surat Edaran Bank Indonesia No.13/ 24/ DPNP tahun 2011

\section{Menetapkan pemeringkatan komposit}

Tabel 2

Kesehatan Bank Metode Risk Based Rating

\begin{tabular}{|c|c|c|c|c|c|c|c|c|c|}
\hline $\mathrm{N}$ & Rasi & & & Tahun & & & Rata & Predika & $\mathrm{P}$ \\
\hline o & o & 2015 & 2016 & 2017 & 2018 & 2019 & rata & $\mathrm{t}$ & K \\
\hline 1. & NPL & $0,65 \%$ & $0,20 \%$ & $0,10 \%$ & $0,12 \%$ & $0,44 \%$ & $\begin{array}{c}0,302 \\
\%\end{array}$ & SS & 1 \\
\hline 2. & LDR & $\begin{array}{c}106,00 \\
\%\end{array}$ & $\begin{array}{c}103,09 \\
\%\end{array}$ & $\begin{array}{c}100,75 \\
\%\end{array}$ & $\begin{array}{c}100,64 \\
\%\end{array}$ & $\begin{array}{c}101,37 \\
\%\end{array}$ & 102,37 & KS & 4 \\
\hline 3. & GCG & 3 & 2 & 2 & 2 & 2 & 2,2 & B & 2 \\
\hline 4. & ROA & $2,43 \%$ & $2,92 \%$ & $3,65 \%$ & $3,06 \%$ & $2,72 \%$ & 2,956 & SS & 1 \\
\hline 5. & NIM & $5,36 \%$ & $5,92 \%$ & $5,92 \%$ & $8,04 \%$ & $5,00 \%$ & 6,048 & SS & 1 \\
\hline 6 & CAR & $28,43 \%$ & $20,90 \%$ & $21,00 \%$ & $24,44 \%$ & $22,78 \%$ & 23,51 & SS & 1 \\
\hline
\end{tabular}

Sumber : data sekunder diolah peneliti, 2020

Masing-masing komponen pada rasio keuangan yang menempati peringkat akan diberikan nilai komposit untuk rasio keuangan masing-masing komponen yang menempati peringkat komposit akan bernilai sebagai berikut :

1. $\mathrm{PK} 1$ = yang berarti dikali 5

2. $\mathrm{PK} 2$ = yang berarti dikali 4 
3. PK 3 = yang berarti dikali 3

4. $\mathrm{PK} 4=$ yang berarti dikali 2

5. PK 5 = yang berarti dikali 1

Setelah penentuan peringkat komposit selanjutnya mempresentasekan masing-masing hasil perhitungan komponen. Penentuan terhadap peringkat komposit dari seluruh komponen penilaian digunakan bobot dalam persentase pada tabel sebagai berikut :

Tabel 3

Peringkat komposit tingkat kesehatan bank Dengan pendekatan Risk Based Bank Rating (RBBR)

\begin{tabular}{|c|c|c|}
\hline Bobot & Peringkat Komposit & Keterangan \\
\hline $86-100$ & PK1 & Sangat Sehat \\
\hline $71-85$ & PK2 & Sehat \\
\hline $61-70$ & PK3 & Cukup Sehat \\
\hline $41-60$ & PK4 & Kurang Sehat \\
\hline$\leq 40$ & PK5 & Tidak Sehat \\
\hline
\end{tabular}

Sumber : Refmasari dan Setiawan (2014)

Tingkat kesehatan Bank Pembangunan Daerah Jambi dari aspek Risk Profile

\section{!. Net Performing Loan (NPL)}

Tabel 4

\section{Kriteria Penetapan Peringkat}

Profil Risiko NPL

\begin{tabular}{ccc}
\hline Peringkat & Keterangan & Kriteria \\
\hline 1 & Sangat sehat & NPL $<2 \%$ \\
\hline 2 & Sehat & $2 \% \leq \mathrm{NPL}<5 \%$ \\
\hline 3 & Cukup Sehat & $5 \% \leq \mathrm{NPL}<8 \%$ \\
\hline 4 & Kurang Sehat & $8 \% \leq \mathrm{NPL}<12 \%$ \\
\hline 5 & Tidak Sehat & $\mathrm{NPL} \geq 12 \%$ \\
\hline
\end{tabular}

Sumber: Surat Edaran Bank Indonesia No.13/ 24/ DPNP tahun 2011 
Tabel 5

Tingkat Kesehatan Bank Pembangunan Daerah Jambi berdasarkan NPL Tahun 2015-2019

\begin{tabular}{lccccccc}
\hline Tahun & $\mathbf{2 0 1 5}$ & $\mathbf{2 0 1 6}$ & $\mathbf{2 0 1 7}$ & $\mathbf{2 0 1 8}$ & $\mathbf{2 0 1 9}$ & $\begin{array}{c}\text { Nilai } \\
\text { Komposit }\end{array}$ & $\begin{array}{c}\text { Kesehatan } \\
\text { bank }\end{array}$ \\
\hline NPL (\%) & $0,65 \%$ & $0,20 \%$ & $0,10 \%$ & $0,12 \%$ & $0,44 \%$ & 25 & $(25 / 25) * 100=$ \\
\hline Peringkat & 1 & 1 & 1 & 1 & 1 & 25 & $100 \%$ \\
\hline Keterangan & SS & SS & SS & SS & SS & PK1 = Sangat Sehat \\
\hline Sumber : data sekunder diolah peneliti, 2020 & & & & \\
\hline
\end{tabular}

Berdasarkan pada tabel 5 nilai total nilai komposit 25 diperoleh dari jumlah komponen penilaian yang berjumlah 5 kemudian dikalikan dengan jumlah peringkat yang ada yaitu 5 . Peringkat komposit yang berada pada PK1 sama artinya dari 2015- 2019 Bank Pembangunan Daerah Jambi berada pada posisi sangat sehat. Sehingga persentase pada Net Performing Loan 25 dari nilai komposit 25 maka penetapan peringkat komposit penilaian tingkat kesehatan bank 25/25*100\% = 100\% maka Net Performing Loan tahun 2015-2019 Bank pembangunan daerah Jambi dikatakan sangat sehat.

Dari sisi kolektibilitas, rasio kredit bermasalah (NPL) Net performing Loan pada tahun 2015 mengalami peningkatan jika dibandingkan dengan tahun 2014 sebesar 0,15\%. Namun pada tahun 2016 berada di posisi 0,20\% yang artinya mengalami penurunan sampai pada tahun 2017, namun pada tahun berikutnya mengalami peningkatan yang tidak terlalu tinggi yaitu pada angka 0,12\% dan peningkatan yang signifikan pada tahun 2019 yaitu 0,44\% akan tetapi belum bisa mencapai angka pada tahun awal penelitian yaitu $0,65 \%$ pada tahun 2015

\section{Loan to Deposit Ratio (LDR)}

Tabel 6

\section{Kriteria Penetapan Peringkat Profil Risiko}

\begin{tabular}{ccc}
\hline Peringkat & Keterangan & Kriteria \\
\hline 1 & Sangat sehat & LDR $\leq 75 \%$ \\
\hline 2 & Sehat & $75 \%<$ LDR $\leq 85 \%$
\end{tabular}




\begin{tabular}{ccc}
\hline 3 & Cukup Sehat & $85 \%<$ LDR $\leq 100 \%$ \\
\hline 4 & Kurang Sehat & $100 \%<$ LDR $\leq 120 \%$ \\
\hline 5 & Tidak Sehat & LDR $>120 \%$ \\
\hline
\end{tabular}

Sumber: Surat Edaran Bank Indonesia No.13/ 24/ DPNP tahun 2011

Tabel 7

Tingkat Kesehatan Bank Pembangunan Daerah Jambi berdasarkan LDR Tahun 2015-2019

\begin{tabular}{|c|c|c|c|c|c|c|c|}
\hline Tahun & 2015 & 2016 & 2017 & 2018 & 2019 & $\begin{array}{c}\text { Nilai } \\
\text { Kompos } \\
\text { it }\end{array}$ & $\begin{array}{c}\text { Kesehatan } \\
\text { bank }\end{array}$ \\
\hline LDR & $106,00 \%$ & $103,09 \%$ & $100,75 \%$ & $100,64 \%$ & $101,37 \%$ & 25 & $\begin{array}{l}(10 / 25) \\
* 100=\end{array}$ \\
\hline Peringkat & 4 & 4 & 4 & 4 & 4 & 10 & $40 \%$ \\
\hline Ket. & SS & SS & SS & SS & SS & \multicolumn{2}{|c|}{ PK5 = Tidak Sehat } \\
\hline
\end{tabular}

Sumber : data sekunder diolah peneliti, 2020

Pada tabel diatas dapat dilihat bahwa Loan to Deposit Ratio Bank Pembangunan Daerah Jambi selama lima tahun dari tahun 2015-2019 terlihat tidak sehat, pemeringkatan ada pada posisi 5 sehingga menghasilkan persentase $10 / 25 * 100=40 \%$, selama 5 tahun dari tahun 20152019 atau terlihat pada tahun penelitian berada pada posisi lebih besar dari yang telah ditentukan oleh bank yaitu $100 \%<$ LDR $\leq 120 \%$.

Tingkat kesehatan Bank Pembangunan Daerah Jambi dari aspek:

Good Corporate Governance (GCG)

Tabel 8

Kriteria Penetapan Peringkat GCG

\begin{tabular}{cc}
\hline Peringkat & Keterangan \\
\hline 1 & Sangat baik \\
\hline 2 & Baik \\
\hline 3 & Cukup baik \\
\hline 4 & Kurang baik \\
\hline
\end{tabular}


Tabel 9

Tingkat Kesehatan Bank Pembangunan Daerah Jambi berdasarkan LDR Tahun 2015-2019

\begin{tabular}{lccccccc}
\hline Tahun & $\mathbf{2 0 1 5}$ & $\mathbf{2 0 1 6}$ & $\mathbf{2 0 1 7}$ & $\mathbf{2 0 1 8}$ & $\mathbf{2 0 1 9}$ & $\begin{array}{c}\text { Nilai } \\
\text { Komposit }\end{array}$ & $\begin{array}{c}\text { Kesehatan } \\
\text { bank }\end{array}$ \\
\hline GCG & 3 & 2 & 2 & 2 & 2 & 25 & $(19 / 25) * 100=$ \\
\hline Peringkat & 3 & 2 & 2 & 2 & 2 & 19 & $76 \%$ \\
\hline Ket. & SS & SS & SS & SS & SS & PK2 = Sehat \\
\hline
\end{tabular}

Sumber : data sekunder diolah peneliti, 2020

Kondisi Good Corporate Governance bank dari tahun 2015-2019 tidak mengalami perubahan dan berada pada posisi peringkat komposit 2, hal ini menunjukan kondisi bank berada pada peringkat sama dari lima tahun tersebut yaitu sehat. Penetapan peringkat komposit bisa dilihat juga pada penilaian tingkat $19 / 25 * 100=76 \%$ dengan arti kata bahwa GCG berada pada posisi sehat selama tahun penelitian.pada awal tahun penelitian terlihat bahwa GCG berada pada posisi 3 hal tersebut secara umum mencerminkan masih adanya beberapa kelemahan penerapan GCG oleh Bank Jambi.

Tingkat kesehatan Bank Pembangunan Daerah Jambi dari aspek:

Return On Asset (ROA)

Tabel 10

Kriteria Penetapan Peringkat Rentabilitas

\begin{tabular}{ccc}
\hline Peringkat & Keterangan & Kriteria \\
\hline 1 & Sangat sehat & ROA $>1,50 \%$ \\
\hline 2 & Sehat & $1,25 \%<\mathrm{ROA} \leq 1.5 \%$ \\
\hline 3 & Cukup Sehat & $0,5 \%<\mathrm{ROA} \leq 1,25 \%$ \\
\hline 4 & Kurang Sehat & $0 \%<\mathrm{ROA} \leq 0,5 \%$ \\
\hline 5 & Tidak Sehat & $\mathrm{ROA} \leq 0 \%$ \\
\hline
\end{tabular}


Tabel 11

Tingkat Kesehatan Bank Pembangunan Daerah Jambi berdasarkan ROA Tahun 2015-2019

\begin{tabular}{lccccccc}
\hline Tahun & $\mathbf{2 0 1 5}$ & $\mathbf{2 0 1 6}$ & $\mathbf{2 0 1 7}$ & $\mathbf{2 0 1 8}$ & $\mathbf{2 0 1 9}$ & $\begin{array}{c}\text { Nilai } \\
\text { Komposit }\end{array}$ & $\begin{array}{c}\text { Kesehatan } \\
\text { bank }\end{array}$ \\
\hline ROA & $2,43 \%$ & $2,92 \%$ & $3,65 \%$ & $3,06 \%$ & $2,72 \%$ & 25 & $(25 / 25) * 100=$ \\
\hline Peringkat & 1 & 1 & 1 & 1 & 1 & 25 & $100 \%$ \\
\hline Ket. & SS & SS & SS & SS & SS & \multicolumn{2}{c}{ PK1 = Sangat Sehat } \\
\hline
\end{tabular}

Sumber : data sekunder diolah peneliti, 2020

Return on Asset digunakan untuk mengukur kemampuan perusahaan dalam memperoleh laba perusahaan dengan menggunakan aktiva. Pada tabel diatas dapat dilihat bahwa ROA dari tahun 2015-2019 terlihat meningkat pada tahun 2017 yaitu pada posisi 3,65\% dan mengalami penurunan pada tahun berikutnya sebesar 3,06\% dan pada periode penelitian pada tahun terakhir merupakan peringkat ke dua dari tahun 2015 yang sangat rendah yaitu $2,43 \%$. Namun pemeringkatan dapat dilihat bahwa ROA berada pada posisi sangat sehat yaitu 25/25*100 = 100\% dengan kata lain nilai komposit Return On Asset sangat sehat.

\section{Net Interests Margin (NIM)}

\section{Tabel 11}

\section{Kriteria Penetapan Peringkat NIM}

\begin{tabular}{ccc}
\hline Peringkat & Keterangan & Kriteria \\
\hline 1 & Sangat sehat & NIM $>3 \%$ \\
\hline 2 & Sehat & $2 \%<\mathrm{NIM} \leq 3 \%$ \\
\hline 3 & Cukup Sehat & $1.5 \%<\mathrm{NIM} \leq 2 \%$ \\
\hline 5 & Kurang Sehat & $1 \%<\mathrm{NIM} \leq 1,5 \%$ \\
\hline 5 & Tidak Sehat & NIM $\leq 1 \%$ \\
\hline
\end{tabular}


Sumber: Surat Edaran Bank Indonesia No. 6/ 23/ DPNP tahun 2004 
Tabel 12

Tingkat Kesehatan Bank Pembangunan Daerah Jambi berdasarkan NIM

Tahun 2015-2019

\begin{tabular}{lccccccc}
\hline Tahun & $\mathbf{2 0 1 5}$ & $\mathbf{2 0 1 6}$ & $\mathbf{2 0 1 7}$ & $\mathbf{2 0 1 8}$ & $\mathbf{2 0 1 9}$ & $\begin{array}{c}\text { Nilai } \\
\text { Komposit }\end{array}$ & $\begin{array}{c}\text { Kesehatan } \\
\text { bank }\end{array}$ \\
\hline NIM & $5,36 \%$ & $5,92 \%$ & $5,92 \%$ & $8,04 \%$ & $5,00 \%$ & 25 & $(25 / 25) * 100=$ \\
\hline Peringkat & 1 & 1 & 1 & 1 & 1 & 25 & $100 \%$ \\
\hline Ket. & SS & SS & SS & SS & SS & PK1 = Sangat Sehat \\
\hline
\end{tabular}

Sumber : data sekunder diolah peneliti, 2020

Rasio ini menggambarkan semakin besar nilai NIM maka akan semakin besar pula keuntungan yang diperoleh dari pendapatan bunga dan akan berpengaruh pada tingkat kesehatan bank. Dilihat dari peringkat penetapan NIM dan dibandingkan di Bank Pembangunan Daerah dimana tahun penelitian dari tahun 2015-2019 berada diatas ketetapan yaitu $>3 \%$. Namun pemeringkatan dapat dilihat bahwa NIM berada pada posisi sangat sehat yaitu $25 / 25 * 100=100 \%$ dengan kata lain nilai komposit Net Interests margin sangat sehat.

Tingkat kesehatan Bank Pembangunan Daerah Jambi dari aspek Capital Capital Adequacy Ratio (CAR)

\section{Tabel 13}

Kriteria penilaian peringkat CAR

\begin{tabular}{ccc}
\hline Peringkat & Keterangan & Kriteria \\
\hline 1 & Sangat sehat & CAR $\geq 11 \%$ \\
\hline 2 & Sehat & $9,5 \% \leq \mathrm{CAR}<11 \%$ \\
\hline 3 & Cukup Sehat & $8 \% \leq \mathrm{CAR}<9,5 \%$ \\
\hline 5 & Kurang Sehat & $6,5 \% \leq \mathrm{CAR}<8 \%$ \\
\hline 5 & Tidak Sehat & $\mathrm{CAR}<6,5 \%$ \\
\hline
\end{tabular}

Sumber: Surat Edaran Bank Indonesia No.13/ 24/ DPNP tahun 2011 
Tabel 14

Tingkat Kesehatan Bank Pembangunan Daerah Jambi berdasarkan CAR Tahun 2015-2019

\begin{tabular}{lccccccc}
\hline Tahun & $\mathbf{2 0 1 5}$ & $\mathbf{2 0 1 6}$ & $\mathbf{2 0 1 7}$ & $\mathbf{2 0 1 8}$ & $\mathbf{2 0 1 9}$ & $\begin{array}{c}\text { Nilai } \\
\text { Komposit }\end{array}$ & $\begin{array}{c}\text { Kesehatan } \\
\text { bank }\end{array}$ \\
\hline CAR & $28,43 \%$ & $20,90 \%$ & $21,00 \%$ & $24,44 \%$ & $22,78 \%$ & 25 & $(25 / 25) * 100=$ \\
\hline Peringkat & 1 & 1 & 1 & 1 & 1 & 25 & $100 \%$ \\
\hline Ket. & SS & SS & SS & SS & SS & PK1 = Sangat Sehat \\
\hline
\end{tabular}

Sumber : data sekunder diolah peneliti, 2020

Pada tabel diatas rasio CAR dari lima tahun penelitian memiliki nilai diatas minimum yaitu $>12 \%$ yang berarti sangat sehat. Hal ini menunjukkan bahwa modal Bank Pembangunan Daerah Jambi bisa menutupi penurunan aktiva sebagai akibat dari kerugian yang disebabkan oleh aktiva. pemeringkatan juga dapat dilihat bahwa CAR berada pada posisi sangat sehat yaitu $25 / 25 * 100=100 \%$ dengan kata lain nilai komposit Capital Adeqacy Ratio sangat sehat.

\section{PENUTUP}

Hasil analisis kesehatan bank dengan menggunakan Risk Based Bank Rating. pada tahun 2015-2019 dilihat dari Aspek risk profile, Net Performing Loan dapat dikatakan sangat sehat karena dilihat secara keseluruhan hasil analisis cenderung berada diatas 2\%, Bank Jambi akan senantiasa melakukan peningkatan, namun salah satu dari risk profile menunjukkan bahwa rata-rata secara keseluruhan Loan to Deposit Ratio dengan predikat Tidak Sehat. Berdasarkan rata-rata faktor Good Coorprate Governance melalui analisis self assesment dapat dikatakan baik, namun pada tahun 2015 berada pada posisi kurang baik, Tingkat kesehatan Bank dari aspek Earning yaitu Return On Assets dan Net Interests Margin sangat sehat, begitu juga dari aspek permodalan yang dihitung dari rasio Capital Adequacy Ratio (CAR) juga sangat sehat.

Disarankan kepada Bank Pembangunan Daerah Jambi untuk memberikan stimulus pada program peningkatan funding pihak ketiga diluar ASN dengan penawaran programprogram kredit yang bersaing dengan Bank konvensional lainnya pada Bank Pembangunan Daerah Jambi. 


\section{DAFTAR PUSTAKA}

Amelia, E., and Astiti Chandra Aprilianti. (2019). Penilaian Tingkat Kesehatan Bank: Pendekatan CAMEL Dan RGEC, Jurnal Akuntansi Dan Keuangan Islam, 6 (2):189-208. Bank Indonesia. (2011). Peraturan Bank Indonesia No. 13/ 1/ PBI/ 2011 Tentang Prosedur dan Mekanisme Penilaian Tingkat Kesehatan Bank.

Bank Indonesia. (2011). Surat Edaran Bank Indonesia Nomor. 13/24/ DPNP/ 2011 pada tanggal 25 Oktober 2011 tentang Penilaian Tingkat Kesehatan Bank Umum.

Dendawijaya, L. (2005). Manajemen Perbankan. Edisi Kedua. Jakarta: Ghalia Indonesia.

Farah, D. (2012). Analisis Rasio Keuangan Perbankan Sebagai Alat Ukur Kinerja Keuangan Bank. 1-11.

Kasmir. (2010). Manajemen Perbankan. Jakarta: Rajawali Press.

Kodifikasi Peraturan Bank Indonesia, Kelembagaan Penilaian Tingkat Kesehatan Bank, Pusat riset dan Edukasi Bank Sentral (PRES) Bank Indonesia. (2012).

Patni, S.S., and Darma, G.S. (2017). Non-Performing Loan, Loan to Deposit Ratio, Net Interest Margin, BOPO, Capital Adequacy Ratio, Return on Asset dan Return on Equity, Jurnal Manajemen \& Bisnis, 14 (2): 166-184.

Refmasari, V.A., dan Setiawan, Ngadirin. (2014). Penilaian Tingkat Kesehatan Bank Umum Menggunakan Metode RGEC Dengan Cakupan Risk Profile, Earnings, dan Capital Pada Bank Pembangunan Daerah Provinsi Daerah Istimewa Yogyakarta Tahun 2012, Jurnal Profita, 2 (1): 41-54.

Sugiyono. (2012). Metode Penelitian Kuantitatif Kualitatif dan R\&B. Bandung: Alfabeta.

Sadikin, A., Fahmi Roy., Dian Masita Dewi., Dahniar, Akhmad Suprianto. (2017). Penggunaan Metode RBBR Dalam Menganalisis Tingkat Kesehatan Bank. 41-61.

Yacheva, N., M. Saifi., and Z. A. 2016. Analisis Tingkat Kesehatan Bank Dengan Metode RBBR (Risk-Based Bank Rating) (Studi Pada Bank Umum Swasta Nasional Devisa Yang Terdaftar Di Bursa Efek Indonesia Periode 2012-2014), Jurnal Administrasi Bisnis S1 Universitas Brawijaya, 37 (1): 37-45. 